\title{
AN ANALYSIS OF THE RESPONSES OF THE ISOLATED PORTAL VEIN OF THE RABBIT TO ELECTRICAL STIMULATION AND TO DRUGS
}

\author{
BY \\ J. HUGHES* AND J. R. VANE \\ From the Department of Pharmacology, Royal College of Surgeons of England, Lincoln's Inn Fields, \\ London
}

(Received October 31, 1966)

Transmural electrical stimulation has been used to investigate responses of isolated intestinal smooth muscle preparations to nerve stimulation (Paton, 1955; Day \& Vane, 1963 ; Paton \& Vane, 1963 ; Birmingham \& Wilson, 1965 ; Burnstock, Campbell \& Rand, 1966). Paterson (1965) stimulated isolated arterial strips transmurally and showed that the ensuing contractions were probably caused by excitation of post-ganglionic adrenergic neurones in the vessel wall.

Isolated venous muscle reacts to drugs (Franklin, 1925 ; Sutter, 1965) but little is known about its response to electrical excitation. We have, therefore, investigated the effects of transmural stimulation on the portal vein of the rabbit; the results show that this tissue has an innervation which can cause both excitatory and inhibitory effects. In addition, there is a non-adrenergic non-cholinergic inhibitory innervation.

\section{METHODS}

Male albino rabbits weighing 2-3 $\mathrm{kg}$ were killed by breaking the neck. The abdomen was opened and the portal vein was exposed and cleared of surrounding tissue. The length of portal vein, starting at the junction of the splenic and the superior mesenteric veins and ending at its bifurcation into right and left branches, was cut out and washed in cold Krebs solution. The vein was opened along its longitudinal axis to form a flat strip of tissue 3-4 cm long. Threads were attached to each end, and the strip was suspended vertically in a $50 \mathrm{ml}$. organ bath containing Krebs solution at $37^{\circ} \mathrm{C}$, gassed with $95 \%$ oxygen and $5 \%$ carbon dioxide. The lower end of the strip was tied to a glass rod, while the upper end was attached to an isometric transducer (tensile sensor, Type S.T.I. Ether-Langham Thompson Ltd.). The transducer formed part of a bridge circuit, the output of which was recorded on a potentiometric millivolt recorder (Texas Instruments ServoRiter) through suitable attenuation. To stimulate the isolated vein, two pairs of parallel platinum wires, $3 \mathrm{~cm}$ long, were mounted longitudinally on opposite internal faces of a Perspex cylinder $4 \mathrm{~cm}$ long and $1 \mathrm{~cm}$ internal diameter. The cylinder was fixed in the organ-bath and the vein was suspended within it. Thus the electrodes lay parallel to the vein on each side of it but not touching it. For transmural stimulation, two stimulators with identical outputs were connected in parallel, in order to give sufficient power output to ensure maximal excitation.

The vein was stimulated with rectangular pulses of $0.5-1 \mathrm{msec}$ duration and full voltage output from the stimulators $(80 \mathrm{~V})$. Stimulus frequencies varying from $15 / \mathrm{min}$ to $50 / \mathrm{sec}$ were used. It was

* Present address: The Department of Surgery, King's College Hospital Medical School, Denmark Hill, London S.E.5. 
impossible to estimate the chronaxie of the structures responding to electrical excitation by using single shocks, since these gave little or no contraction. The strength/duration curve was, therefore, plotted using a frequency of $20 / \mathrm{sec}$.

In a few experiments, segments of human umbilical artery and vein, obtained at time of delivery, were dissected out and longitudinal strips were prepared in a similar way to that described above.

The Krebs solution had the following composition in m-equiv/l. $\mathrm{NaCl} 118, \mathrm{CaCl}_{2} .6 \mathrm{H}_{2} \mathrm{O} 5.05$, $\mathrm{KH}_{2} \mathrm{PO}_{4} 1.18, \mathrm{MgSO}_{4} .7 \mathrm{H}_{2} \mathrm{O} 2.34, \mathrm{NaHCO}_{3} 25$, and glucose 11.1. The following agonists were used: acetylcholine perchlorate (B.D.H.), adenosine triphosphate, diphosphate and monophosphate (B.D.H.), (-)-adrenaline bitartrate (B.D.H.), synthetic angiotensin (Hypertensin-Ciba), 3,4, dihydroxyphenylalanine (dopa, Sigma), dopamine hydrochloride (Sigma), histamine hydrogen phosphate (B.D.H.), 5-hydroxytryptamine creatinine sulphate (May \& Baker), ( \pm )-isopropylnoradrenaline sulphate (B.D.H.), (-)-nicotine hydrogen tartrate (B.D.H.), synthetic oxytocin (Sandoz), veratrine (B.D.H.) and synthetic lysine-vasopressin (Sandoz).

The following antagonists were used: bethanidine sulphate (Burroughs Wellcome), bretylium tosylate (B.W.), brom-lysergic acid diethylamide hydrogen tartrate (Sandoz), cocaine hydrochloride (B.D.H.), dexamphetamine sulphate (Smith, Kline \& French), ergotamine tartrate (Sandoz), hexamethonium bromide (May \& Baker), hyoscine hydrobromide (B.D.H.), lignocaine hydrochloride (Duncan, Flockhart), mecamylamine hydrochloride (Merck, Sharp and Dohme), mepyramine maleate (B.D.H.), 1-(p-nitrophenyl-2-isopropylamine ethanol hydrochloride (dl-INPEA), phentolamine methanesulphonate (Ciba), reserpine (ampoules $2.5 \mathrm{mg} / \mathrm{ml}$., Ciba) and tetrodotoxin (Sankyo-Tokyo).

All drugs were freshly diluted in saline $(0.9 \%, \mathrm{w} / \mathrm{v})$ from stock solutions. The doses of the salts are expressed in terms of base and as final bath concentration $(\mathrm{g} / \mathrm{ml}$.$) , unless otherwise stated.$

\section{RESULTS}

\section{Effects of initial tension on responses}

Over 150 preparations have been studied. Within $10 \mathrm{~min}$ of starting the experiment they all exhibited spontaneous rhythmic activity at frequencies of $3-8 / \mathrm{min}$. During the next $30 \mathrm{~min}$, the amplitude of the spontaneous activity generally increased and then became phasic with periods of high activity alternating with periods of low activity (Fig. 1a).

In about $70 \%$ of the preparations the basal tension remained at that set initially and, apart from the rhythmic activity, varied little over 6-8 hr (Fig. 1b). In the others, the basal tension tended to increase over the first 1-2 hr and thereafter remained high (3-6 g tension, Fig. 1c); in these, the spontaneous activity declined and sometimes disappeared completely. In nine experiments, the spontaneous activity and sub-maximal responses both to noradrenaline and to electrical excitation were recorded at differing basal tensions. The responses to transmural stimulation and to noradrenaline tended to increase with basal tension until, between 3-6 gm, they remained fairly constant (Fig. 2). In the following experiments, therefore, the initial tension was set at 3-4 $\mathrm{g}$ and the preparation was allowed to stabilize before testing drugs or electrical excitation.

\section{Effects of drugs}

Adrenaline, noradrenaline, acetylcholine, 5-hydroxytryptamine (5HT) and histamine contracted the isolated portal vein; typical dose-response curves are shown in Fig. 3. For histamine, 5-HT and acetylcholine, the curves were very flat and none of these agonists gave a contraction as great as that elicited by maximal concentrations of adrenaline or noradrenaline. 


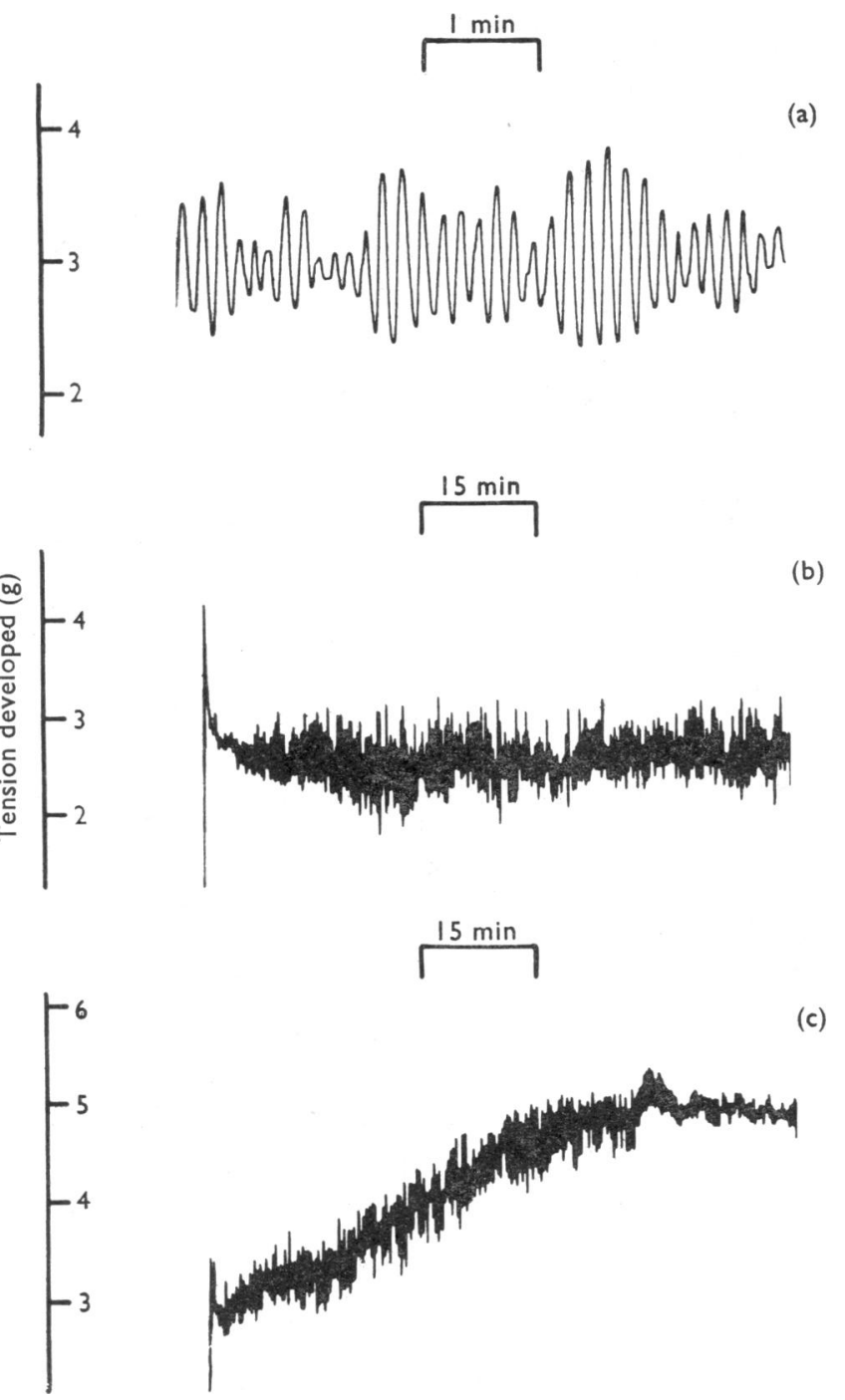

Fig. 1. Spontaneous activity and tone in the isolated portal vein. Panel (a) shows phasic spontaneous activity of the vein at optimum basal tension. Panel (b) shows an experiment in which the basal tension of the vein remained at that set initially. Panel (c) shows an experiment in which the basal tension increased slowly from that set initially. The spontaneous activity declines in this type of preparation. The vertical scale in this and in subsequent figures is the tension developed (g). Time scale $1 \mathrm{~min}$ in (a) and $15 \mathrm{~min}$ in (b) and (c).

Angiotensin $\left(2 \times 10^{-7}-10^{-5} \mathrm{~g} / \mathrm{ml}\right.$.) usually elicited a brisk contraction, thereafter the tissue exhibited tachyphylaxis and graded responses could not be obtained. The rate of relaxation after a contraction induced by angiotensin was slower than that after noradrenaline.

Isoprenaline $\left(10^{-8}-10^{-6} \mathrm{~g} / \mathrm{ml}.\right)$, relaxed the isolated vein, as did ATP, ADP and AMP $\left(10^{-7}-10^{-5} \mathrm{~g} / \mathrm{ml}\right.$.), oxytocin $(20-200 \mathrm{mU} / \mathrm{ml}$.) and vasopressin $(10-100 \mathrm{mU} / \mathrm{ml}$.). In 




Fig. 2. Effect of increasing basal tension on the amplitude of spontaneous activity ( $\square)$, on contractions to electrical stimulation at $5 / \sec (\odot)$ and $20 / \sec (O)$; and to $30 \mu \mathrm{g}$ noradrenaline $(X)$.

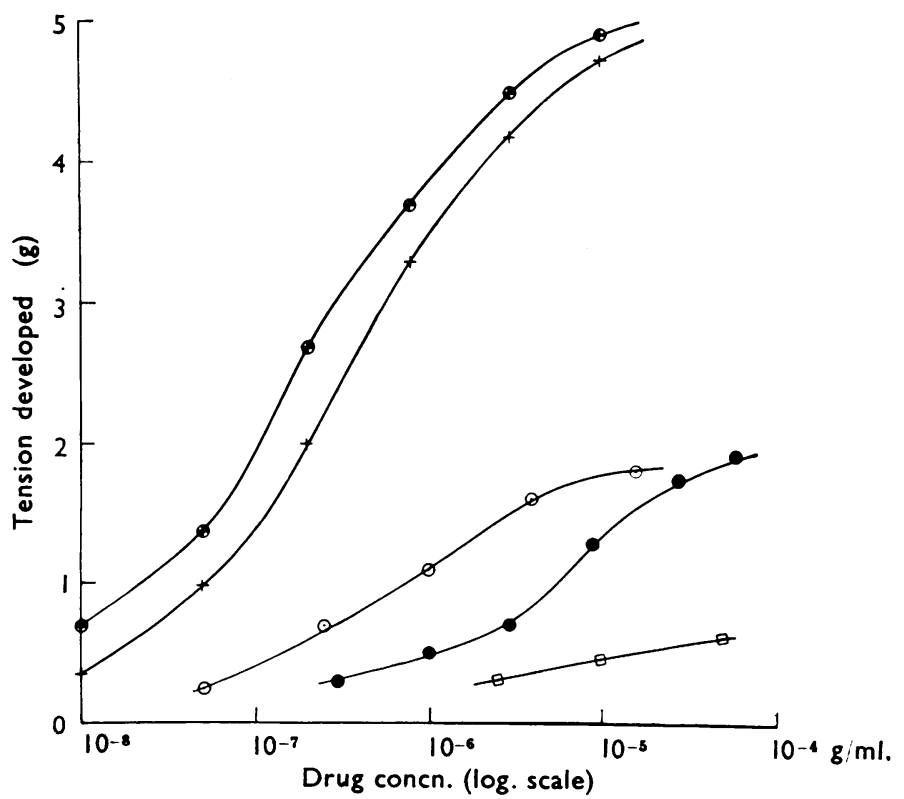

Fig. 3. Typical dose/response curves for adrenaline $(\otimes)$, noradrenaline $(\times)$, acetylcholine $(\odot)$, 5-HT (O) and histamine ( $\square$ ). 
a few preparations acetylcholine initially caused a relaxation. When this occurred, increasing the dose of acetylcholine induced either a biphasic response or a contraction.

Hyoscine $\left(10^{-7} \mathrm{~g} / \mathrm{ml}\right.$.) completely abolished the effects of acetylcholine, mepyramine $\left(10^{-8} \mathrm{~g} / \mathrm{ml}\right.$.) abolished the effects of histamine and brom-lysergic acid diethylamide $\left(10^{-7} \mathrm{~g} / \mathrm{ml}\right.$.) the effects of 5-HT. These antagonisms were specific.

\section{Effects of electrical stimulation}

To determine the voltage necessary to elicit a maximal response, five preparations were stimulated at $20 / \mathrm{sec}$ for periods of $15 \mathrm{sec}$ at varying voltages. The maximal response was obtained at $70 \%$ of maximum output ; for all subsequent experiments the stimulator was, therefore, set to give full output. Single transmural shocks sometimes elicited a small contraction of the vein, but this was hardly distinguishable from the background spontaneous activity. With repetitive stimulation a rapid contraction was elicited which increased with the frequency of excitation until a maximal response was reached at $30-40 / \mathrm{sec}$ (Fig. 4); at frequencies higher than $40 / \mathrm{sec}$ the response declined.

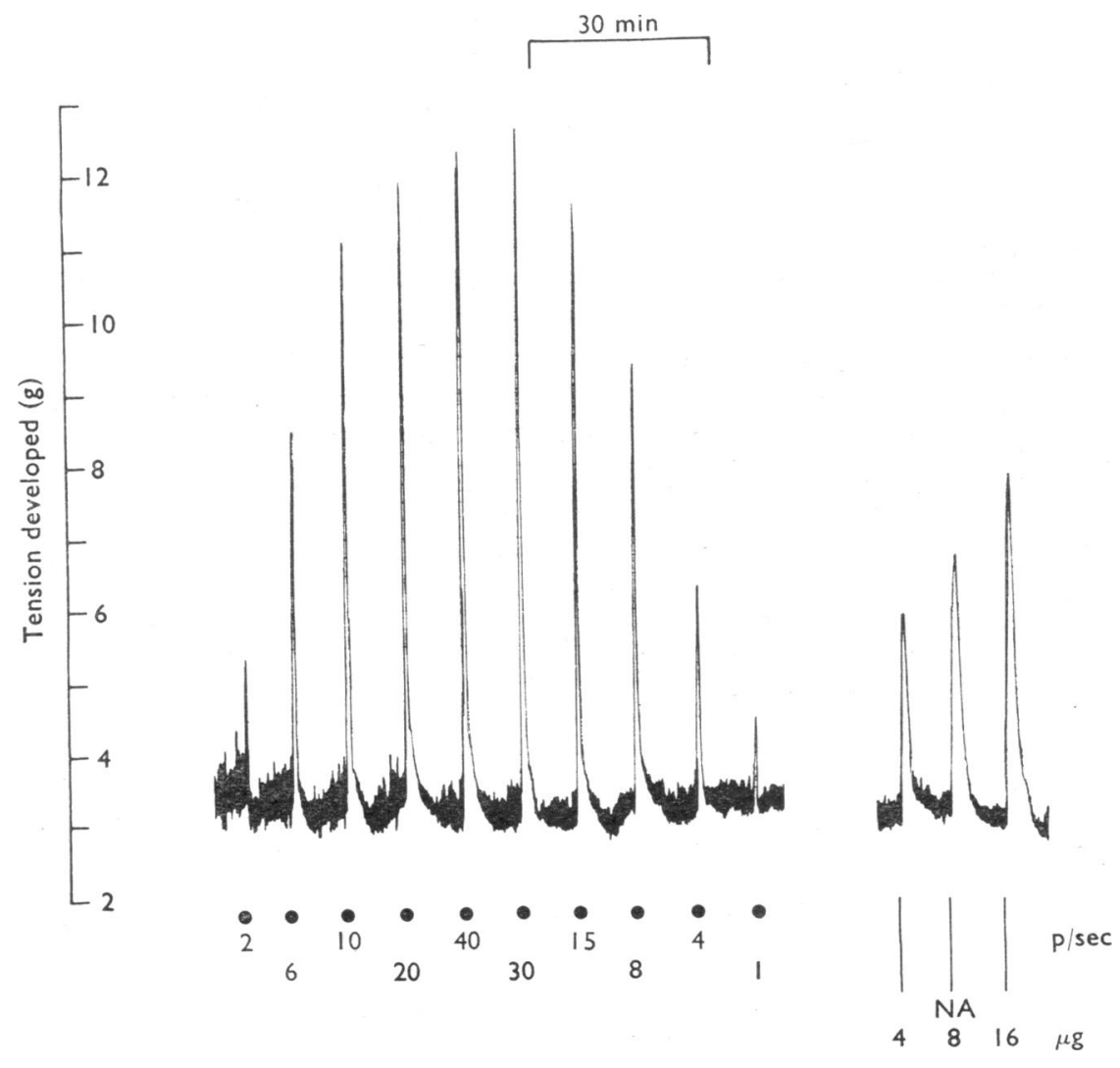

Fig. 4. Preparation stimulated both electrically and chemically. At the dots, electrical stimulation for $10 \mathrm{sec}$ at different frequencies $(\mathrm{p} / \mathrm{sec})$. Note that maximal contraction occurred at 30/sec. At the lines, doses of noradrenaline (NA, 4, 8 and $16 \mu \mathrm{g}$ ). Time scale $30 \mathrm{~min}$. 
The maximum tensions developed by the tissues were 8-13 $\mathrm{g}$ and a frequency of $4-6 / \mathrm{sec}$ usually elicited $50 \%$ of the maximum response. With a frequency of $4-6 / \mathrm{sec}$ applied for $10 \mathrm{sec}$ every $5 \mathrm{~min}$, the responses decline slightly over the first hour and then remain constant for several hours.

In those preparations where the basal tension increased spontaneously during the first $2 \mathrm{hr}$, low frequencies of stimulation (15-30/min) always elicited a relaxation. However, in the same preparation, noradrenaline and adrenaline only caused a contraction. With increased frequency of stimulation a contraction was elicited; this was followed by an after-relaxation below the baseline (Fig. 5). Even in preparations which did not gain tone, an after-relaxation to higher rates of stimulation was frequently observed. In those preparations which showed an after-relaxation to electrical excitation, an after-relaxation was also seen following the removal of high concentrations $\left(10^{-6}-10^{-5} \mathrm{~g} / \mathrm{ml}\right.$.) of noradrenaline and adrenaline from the bathing fluid.

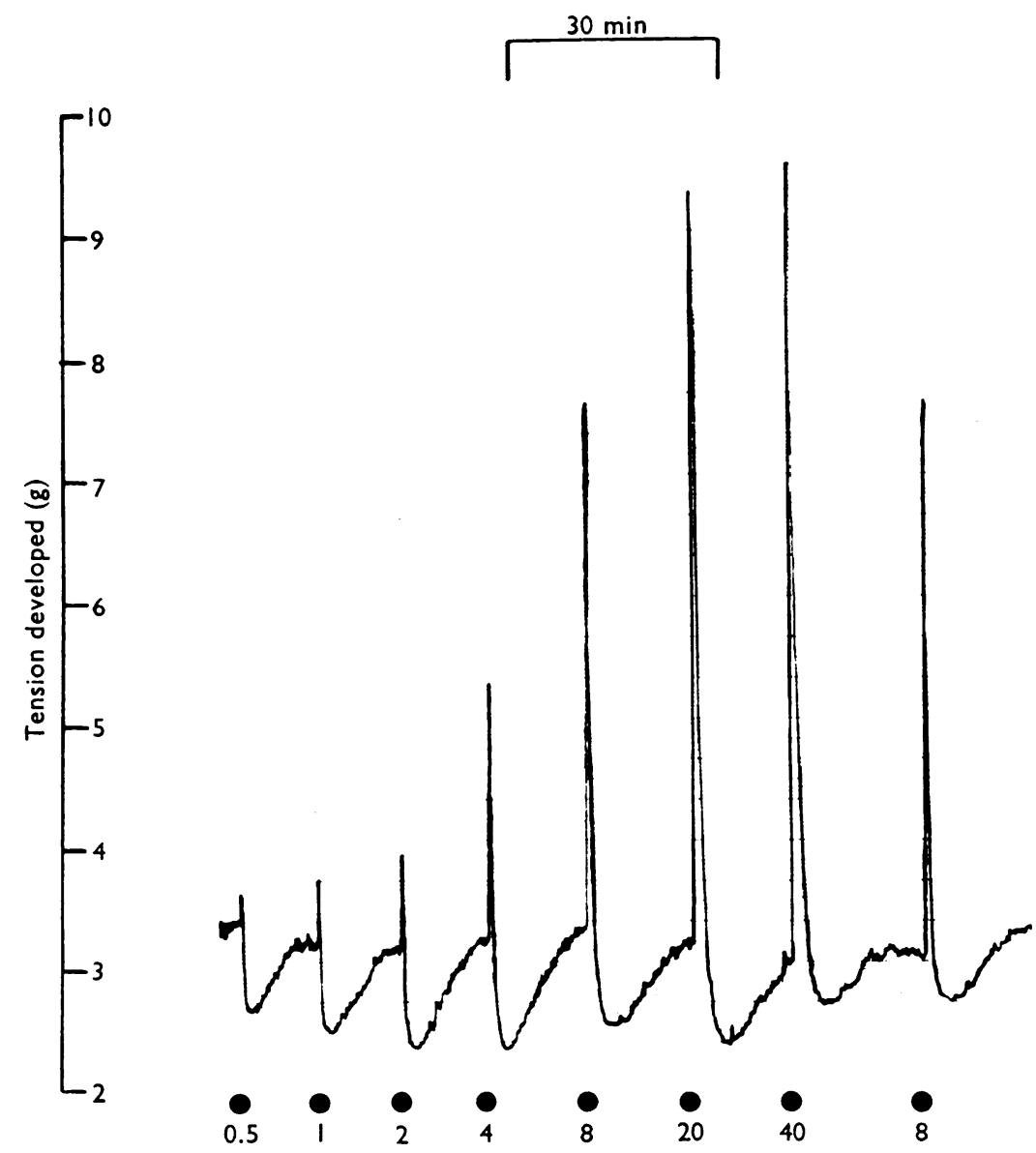

Fig. 5. Relaxation to electrical stimulation (at dots in pulses/sec) at low frequencies, and afterrelaxation following the contraction at higher frequencies. This preparation showed an increase in basal tension at the start of the experiment. Time scale $30 \mathrm{~min}$. 
Characteristics of the responses. The contraction of the isolated portal vein to noradrenaline reached a maximum in 60-90 sec. When the noradrenaline was washed out, the tissue slowly relaxed and returned to its resting tension within $2-5 \mathrm{~min}$. By contrast, the response to transmural electrical excitation at higher frequencies was rapid, taking only 10-30 sec to reach its maximum. The tissue began to relax as soon as the excitation was stopped, falling to the initial tension within 60-120 sec. Typical responses to noradrenaline and to electrical excitation are shown at a fast paper speed in Fig. 6a.

(a)

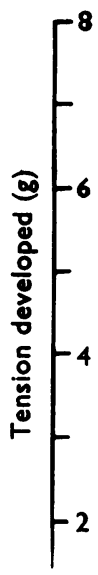

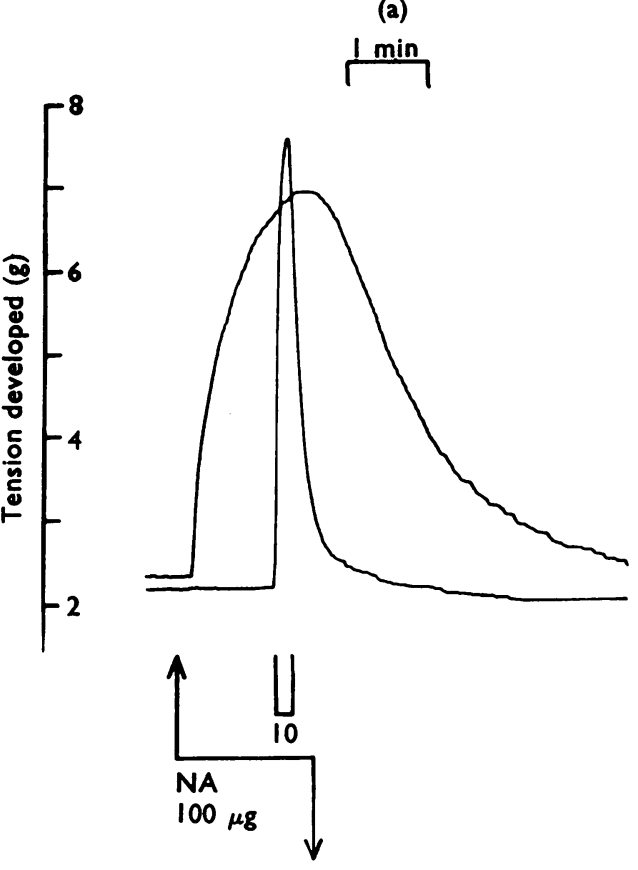

(b)
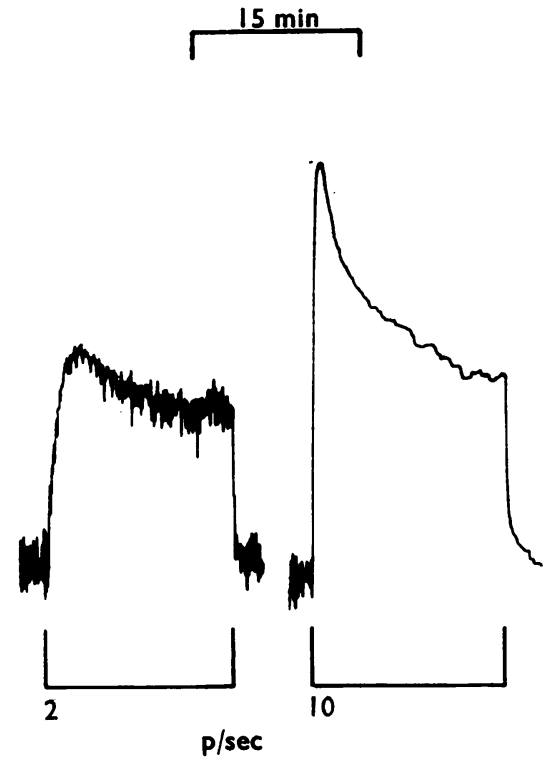

Fig. 6. Panel (a) shows contractions to noradrenaline (NA $100 \mu \mathrm{g}$ ), and to electrical stimulation $(10 \mathrm{p} / \mathrm{sec})$ superimposed at fast paper speed ; each stimulus was allowed to exert its maximum effect. Panel (b) shows the effects of continuous electrical stimulation at low $(2 \mathrm{p} / \mathrm{sec})$ and high $(10 \mathrm{p} / \mathrm{sec})$ frequencies. Time scale $1 \mathrm{~min}$ in (a) and $15 \mathrm{~min}$ in (b).

When the preparation was excited at a low frequency $(1-5 / \mathrm{sec})$ it maintained an increase of tension for as long as the stimulation was continued (Fig. 6b). At the higher rates $(10-30 / \mathrm{sec})$ the tissues relaxed to about half of the peak response within $10-15 \mathrm{~min}$, even though the excitation was maintained (Fig. 6b).

The nature of the structures responding to electrical stimulation. The conclusion that the responses to transmural stimulation result from excitation of nervous tissue is based not only upon the effects of antagonists (which are described later) but also upon the following experiments.

1. Estimates of the "chronaxie" were made in 10 experiments, and yielded values of between 0.1 and $0.5 \mathrm{msec}$. 
2. Local anaesthetics such as lignocaine $\left(10^{-5} \mathrm{~g} / \mathrm{ml}\right.$.), or cocaine $\left(10^{-5} \mathrm{~g} / \mathrm{ml}\right.$.) abolished the responses to excitation at all frequencies without reducing the effects of noradrenaline.

3. Veratrine $\left(5 \times 10^{-6} \mathrm{~g} / \mathrm{ml}\right.$.), which causes repetitive firing in nerves, increased the effects of transmural excitation at low frequencies; the response to noradrenaline remained unchanged (Fig. 7).

4. The contraction to transmural excitation was completely abolished by tetrodotoxin $\left(5 \times 10^{-7} \mathrm{~g} / \mathrm{ml}\right.$.) which at this concentration selectively paralyses nerves (Narahashi, Moore \& Scott, 1964 ; Bülbring \& Tomita, 1966). The effects of noradrenaline were unchanged.

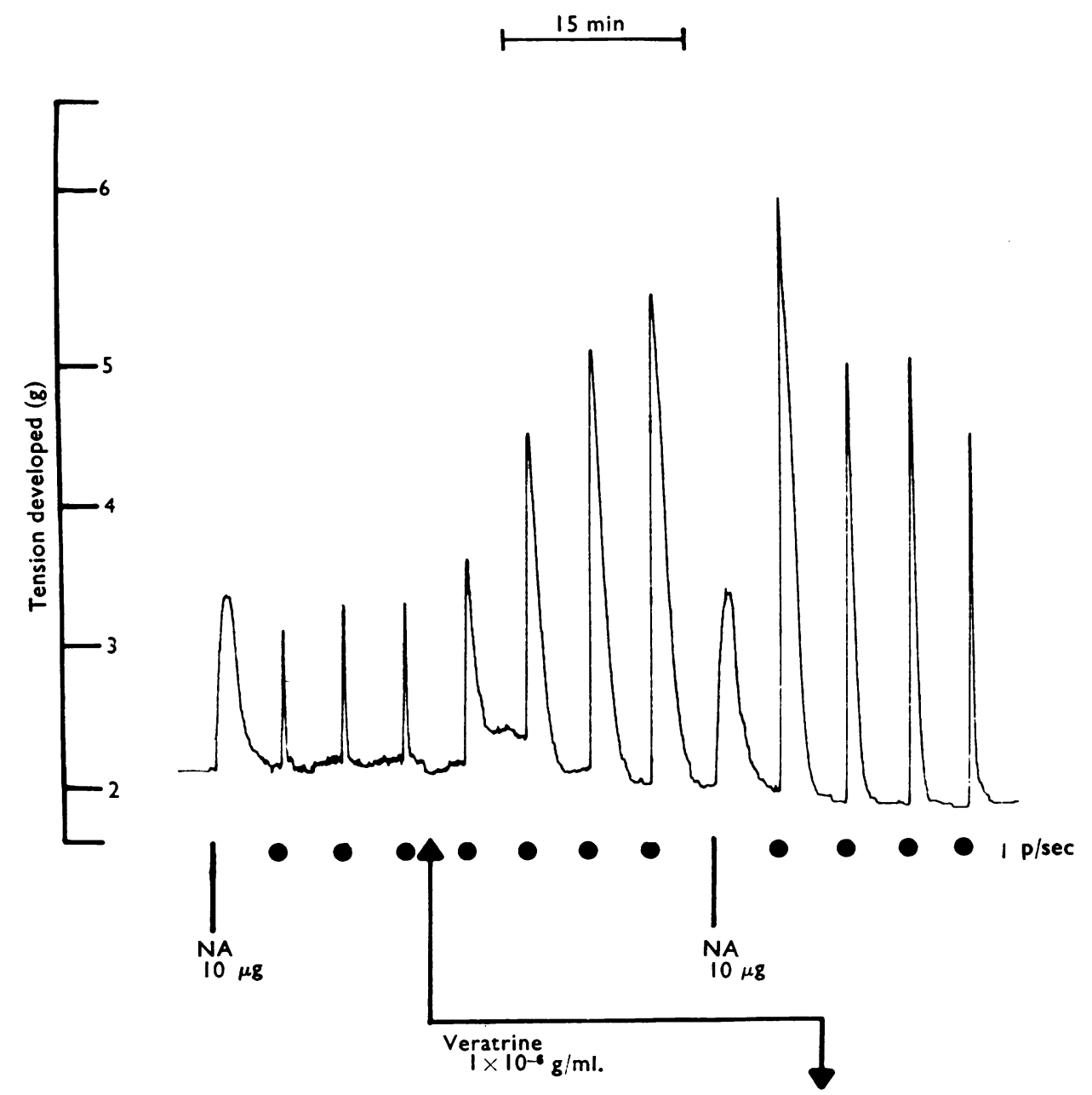

Fig. 7. Potentiation of contraction to low frequency stimulation $(1 \mathrm{p} / \mathrm{sec}$ at dots) by veratrine $\left(1 \times 10^{-6} \mathrm{~g} / \mathrm{ml}\right.$. maintained in the bath between the arrows). Control response to noradrenaline (NA, $10 \mu \mathrm{g}$ ) was not potentiated. Time scale $15 \mathrm{~min}$. 
5. Umbilical arteries and veins are not innervated (Spivack, 1943); electrical stimulation of segments from these vessels gave no responses, even though the preparation contracted to noradrenaline $\left(5 \times 10^{-6} \mathrm{~g} / \mathrm{ml}\right.$.) and 5-hydroxytryptamine $\left(10^{-6} \mathrm{~g} / \mathrm{ml}\right.$.).

\section{Effects of antagonists}

Neither the contractions nor the relaxations induced by electrical stimulation were reduced in amplitude or shortened in duration by hyoscine, mepyramine or brom-LSD in concentrations $\left(10^{-7} \mathrm{~g} / \mathrm{ml}\right.$.) sufficient to abolish responses to acetylcholine, histamine and 5-HT respectively.



Fig. 8. Effect of cocaine on matched contractions to electrical stimulation $(1 \mathrm{p} / \mathrm{sec}$ at dots), Noradrenaline (NA, $20 \mu \mathrm{g}$ ), adrenaline (AD $5 \mu \mathrm{g}$ ) and acetylcholine (Ach, $80 \mu \mathrm{g}$ ). Upper panel shows equal potentiation of noradrenaline and of electrical stimulation by cocaine $\left(5 \times 10^{-7}\right.$ $\mathrm{g} / \mathrm{ml}$.) ; adrenaline was potentiated to a lesser extent, and acetylcholine was unaffected. An increase in the cocaine concentration to $1 \times 10^{-5} \mathrm{~g} / \mathrm{ml}$. (lower panel) blocked the contraction to electrical stimulation, but not to NA, AD and Ach. Removal of the cocaine from the bath restored the response to stimulation. Time scale $15 \mathrm{~min}$. 
Local anaesthetic drugs. Apart from the abolition of response to electrical excitation (see earlier) lower concentrations of lignocaine and cocaine $\left(5 \times 10^{-8}\right.$ to $5 \times 10^{-7} \mathrm{~g} / \mathrm{ml}$.) potentiated both the contractions induced by electrical excitation and those produced by adrenaline and noradrenaline. The potentiation of noradrenaline was to the same extent as that for electrical excitation, whereas responses to adrenaline were potentiated to a lesser extent (Fig. 8). The contractions were increased both in height and in duration; those induced by 5-HT or acetylcholine were not affected (Fig. 8). The block of transmural stimulation by high concentrations of lignocaine and cocaine was reversed within 40-60 min after washing out the bath; however, the potentiation of catecholamine effects was not easily reversed. The dose/response curves in Fig. 9 show that, whereas,

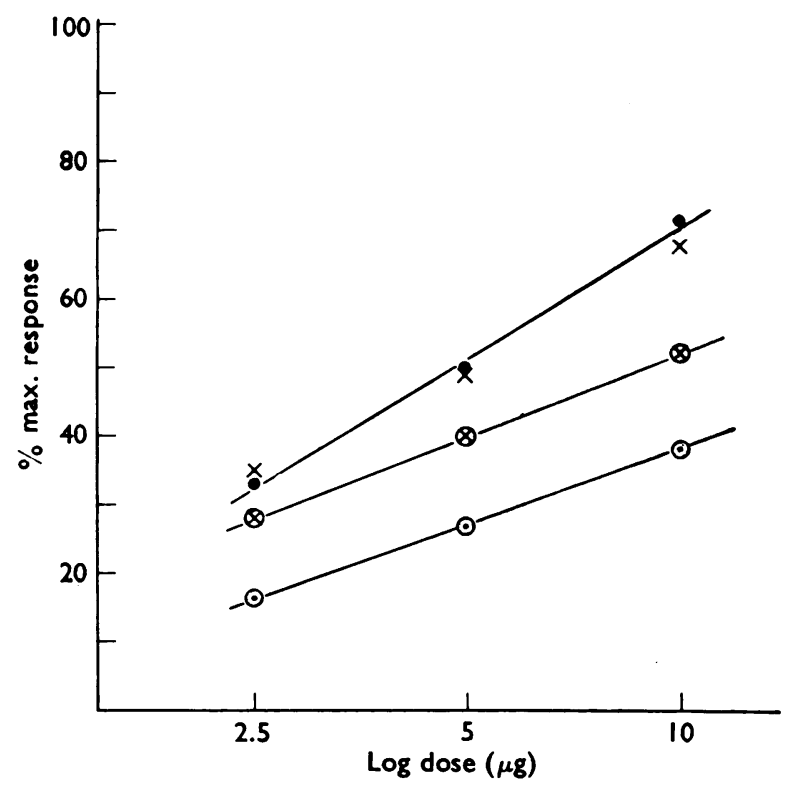

Fig. 9. Dose/response lines for noradrenaline and adrenaline before and after treatment of the vein with cocaine $\left(1 \times 10^{-6} \mathrm{~g} / \mathrm{ml}\right.$.). ( $(\odot)$ Noradrenaline before cocaine, $(O)$ after cocaine ; $(\otimes)$ adrenaline before cocaine, $(\times)$ after cocaine. Each point is the mean of two determinations.

before cocaine, noradrenaline was about one-quarter as active as adrenaline, it was approximately equiactive in the presence of cocaine $\left(10^{-6} \mathrm{~g} / \mathrm{ml}\right.$.). This differential potentiation may be related to greater uptake of noradrenaline than of adrenaline into tissue stores (Iversen, 1965).

Drugs acting at ganglia. Neither hexamethonium (up to $10^{-4} \mathrm{~g} / \mathrm{ml}$., four experiments) nor mecamylamine $\left(10^{-4} \mathrm{~g} / \mathrm{ml}\right.$, , one experiment) affected the response of the isolated portal vein to electrical excitation. Nicotine and DMPP $\left(10^{-6}-10^{-5} \mathrm{~g} / \mathrm{ml}\right.$.) both caused small contractions but the presence of nicotine did not affect the response to electrical stimulation. With DMPP however, there was some reduction in the response to stimulation (two experiments). It has been shown (Bentley, 1962; Wilson, 1962) that DMPP has an adrenergic neurone blocking action. 
Drugs acting on adrenergic neurones. Bretylium (30 experiments) and bethanidine (nine experiments) both caused progressive block of the contraction elicited by electrical excitation. Responses to low frequencies were more susceptible than those to high frequencies. At $5 \times 10^{-7} \mathrm{~g} / \mathrm{ml}$. the diminution of effect was slow, taking 30-60 min to reach equilibrium; with this concentration block was never complete. At $2 \times 10^{-6} \mathrm{~g} / \mathrm{ml}$. the decline of the contraction induced by electrical stimulation was much more rapid and complete abolition of the contraction was obtained within 15-30 min. The responses to noradrenaline were substantially potentiated by adrenergic neurone blocking agents whereas those to 5-HT and acetylcholine were not much affected. Some of these effects are shown in Fig. 10. Bretylium and bethanidine $\left(5 \times 10^{-6} \mathrm{~g} / \mathrm{ml}\right.$.) sometimes caused a



Fig. 10. Block of electrical stimulation by bretylium and restoration by dexamphetamine. Contractions to stimulation (dots, $10 \mathrm{p} / \mathrm{sec}$ ) were completely abolished within $10 \mathrm{~min}$ of introducing bretylium $\left(2 \times 10^{-6} \mathrm{~g} / \mathrm{ml}\right.$. $\left.\uparrow\right)$ into the bath. Contractions to noradrenaline (NA, $\left.10 \mu \mathrm{g}\right)$ were potentiated but the contraction to acetylcholine (Ach, $500 \mu \mathrm{g}$ ) was only slightly potentiated. Removing the bretylium ( $\square$ ) did not restore the contraction to stimulation but addition of $\left(1 \times 10^{-6} \mathrm{~g} / \mathrm{ml}\right.$.) dexamphetamine induced, as well as a small contraction, an immediate reversal of the bretylium block. Time scale $15 \mathrm{~min}$.

small increase in the resting tension of the vein when first added to the bath, but this was not maintained. This effect might be linked with an initial release of catecholamines by these substances (Boura \& Green, 1959 ; Cass \& Spriggs, 1961 ; Kirpekar \& Furchgott, 1964).

The block of contractor responses to electrical excitation was long lasting and, despite repeated washes, could not easily be reversed. However, as shown by Day (1962) and Day \& Rand (1963) with other sympathetically innervated organs, dexamphetamine rapidly reversed the antagonism. Dexamphetamine $\left(10^{-6} \mathrm{~g} / \mathrm{ml}\right.$.), which itself caused a small contraction, completely restored the contraction to electrical excitation within 10-15 min (Fig. 10).

In those experiments in which adrenergic neurone block led to a complete abolition of the contractor response and its associated after-relaxation, a quick relaxation to electrical stimulation appeared. This was a rapid response and the vein regained its resting tension within $90-120 \mathrm{sec}$ of stopping the electrical stimulation. This relaxation, which survived adrenergic neurone block, will be analysed more fully later. 
Preparations from rabbits pretreated with reserpine. Three rabbits were treated with reserpine $(1 \mathrm{mg} / \mathrm{kg}$ intramuscularly, on day 1 , and $3 \mathrm{mg} / \mathrm{kg}$ intraperitoneally on day 2$)$. The portal veins were removed on day 3 . These preparations gave a relaxation to electrical stimulation, an effect indistinguishable from that seen after complete adrenergic neurone block. They contracted in response to noradrenaline, adrenaline, dopamine, 5-HT and acetylcholine, but even prolonged contact with high concentrations $\left(10^{-5} \mathrm{~g} / \mathrm{ml}\right.$.) of these substances did not restore the contractor response to electrical stimulation. Dopa $\left(10^{-5}\right.$ $\mathrm{g} / \mathrm{ml}$.) and dexamphetamine $\left(10^{-6} \mathrm{~g} / \mathrm{ml}\right.$.) also failed to restore the contractions. The small contraction normally caused by dexamphetamine was absent in the preparations pretreated with reserpine.
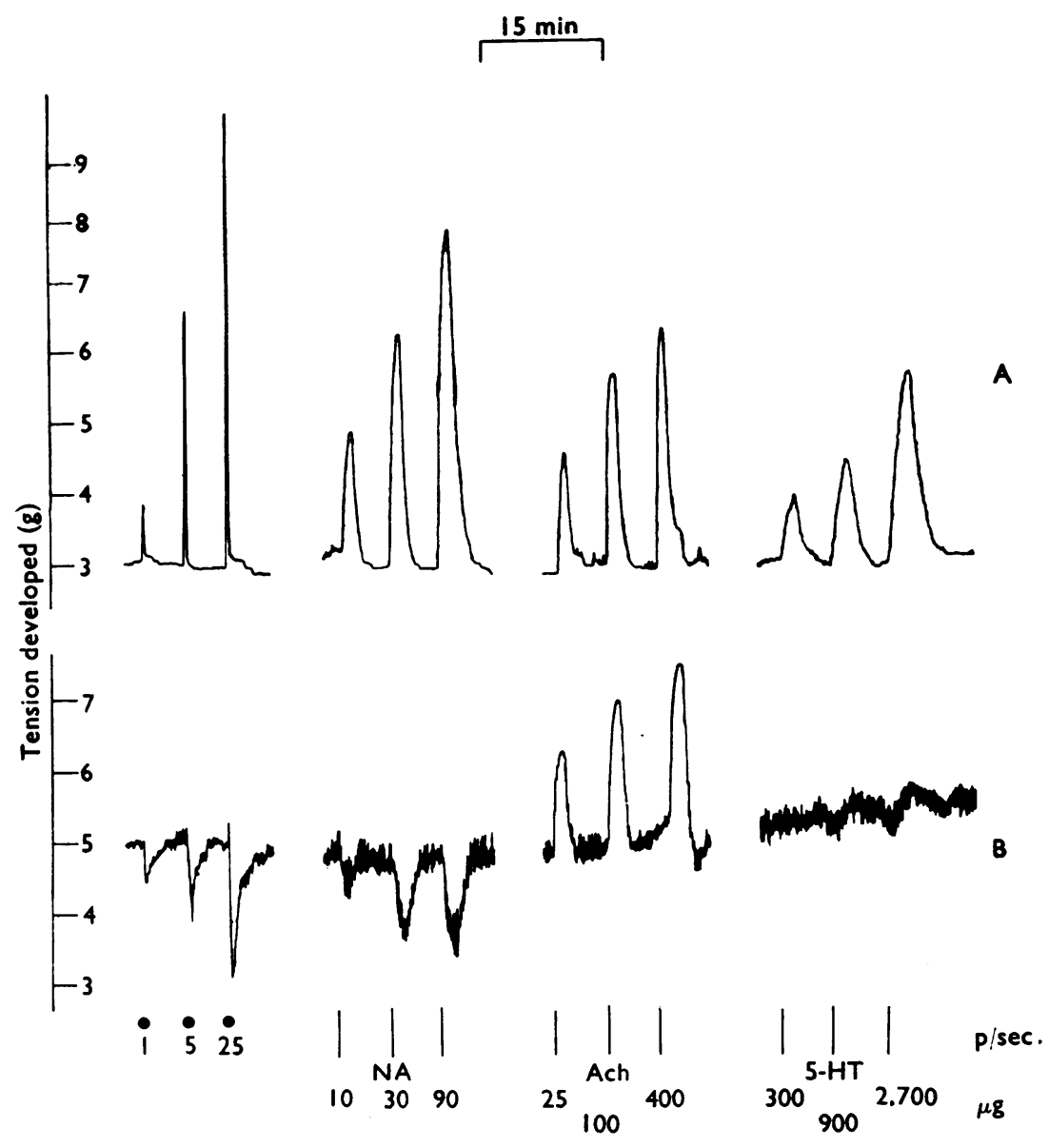

Fig. 11. Block of $\alpha$-receptors for catecholamines by phentolamine. The upper panel shows responses to stimulation $(1 \mathrm{p} / \mathrm{sec}, 5 \mathrm{p} / \mathrm{sec}, 20 \mathrm{p} / \mathrm{sec}$ at dots) to noradrenaline $(\mathrm{NA} ; 10,30$ and $90 \mu \mathrm{g}$ ); acetylcholine (Ach: 25,100 and $400 \mu \mathrm{g}$ ); and to 5-hydroxytryptamine (5-HT, 300, 900 and 2,700 $\mu \mathrm{g}$ ). The lower panel shows the effects of these stimuli $20 \mathrm{~min}$ after addition of phentolamine $\left(5 \times 10^{-6} \mathrm{~g} / \mathrm{ml}\right.$.). The basal tension has been increased to show the relaxant effects more clearly. Time scale $15 \mathrm{~min}$. 
Two other rabbits were given reserpine $(1 \mathrm{mg} / \mathrm{kg}$ intramuscularly) and the veins prepared $24 \mathrm{hr}$ later. These tissues showed a small contraction to electrical stimulation $(20 / \mathrm{sec})$ but these contractions were not enhanced by noradrenaline, adrenaline, dopamine or acetylcholine.

All of the preparations taken from rabbits pretreated with reserpine maintained a high resting tension and showed large amplitude waves of spontaneous activity.

Antagonists of $\alpha$-receptors for catechol amines. Phentolamine $\left(5 \times 10^{-7}-5 \times 10^{-6}\right.$ $\mathrm{g} / \mathrm{ml}$., 25 experiments) caused a progressive block of the contractions and associated after-relaxations elicited by electrical stimulation and by adrenaline and noradrenaline. Contractions induced by acetylcholine were slightly reduced whereas those induced by 5-HT were almost abolished. The rate of development of the block was greater at lower frequencies of stimulation; for instance, with phentolamine $\left(5 \times 10^{-7} \mathrm{~g} / \mathrm{ml}\right.$.) the response to $5 / \mathrm{sec}$ was reduced by $50 \%$ in $6-8 \mathrm{~min}$, whereas it took $10-15 \mathrm{~min}$ to reduce the response to $25 / \mathrm{sec}$ by $50 \%$.

With phentolamine concentrations of $10^{-6} \mathrm{~g} / \mathrm{ml}$. or more, the responses to noradrenaline, to adrenaline and to electrical stimulation were reversed and relaxant effects were seen (Fig. 11). The relaxation to electrical stimulation in the presence of phentolamine was of a much shorter time course than the after-relaxation following a contraction. Adrenaline and noradrenaline were approximately equipotent in producing relaxations (four experiments) although they were 10-20 times less active than isoprenaline. Phenoxybenzamine $\left(10^{-7}-10^{-6} \mathrm{~g} / \mathrm{ml}\right.$, five experiments) produced similar antagonisms to those seen with phentolamine.



Fig. 12. Effect of ergotamine on portal vein. Addition of ergotamine $\left(5 \times 10^{-6} \mathrm{~g} / \mathrm{ml}\right.$.) at the arrow caused a slowly developing sustained contraction. Complete block of the contraction induced by electrical stimulation occurred within $75 \mathrm{~min}$. Time scale $15 \mathrm{~min}$. 
Ergotamine $\left(5 \times 10^{-7}-5 \times 10^{-6} \mathrm{~g} / \mathrm{ml}\right.$.) caused a sustained contraction of the vein (Fig. 12) and the development of $\alpha$-receptor block was slower than with phentolamine. Electrical stimulation first produced a contraction and after-relaxation, as is often seen when the tone of the preparation is raised. As the block developed, the contraction and time course of the after-relaxation decreased leaving the characteristic relaxation seen after $\alpha$-receptor block with phentolamine. The direct contractor activity, coupled with its $\alpha$-receptor blocking properties, made ergotamine a particularly useful drug for examining inhibitory responses.

Antagonists of $\beta$-receptors for catechol amines. Propranolol $\left(10^{-7}-10^{-6} \mathrm{~g} / \mathrm{ml}.\right)$, pronethalol $\left(10^{-7}-10^{-6} \mathrm{~g} / \mathrm{ml}\right.$.) or INPEA $\left(10^{-6}-10^{-5} \mathrm{~g} / \mathrm{ml}\right.$.) completely abolished the relaxation induced by isoprenaline $\left(10^{-7}-10^{-6} \mathrm{~g} / \mathrm{ml}\right.$.). At higher concentrations $\left(5 \times 10^{-6}-\right.$

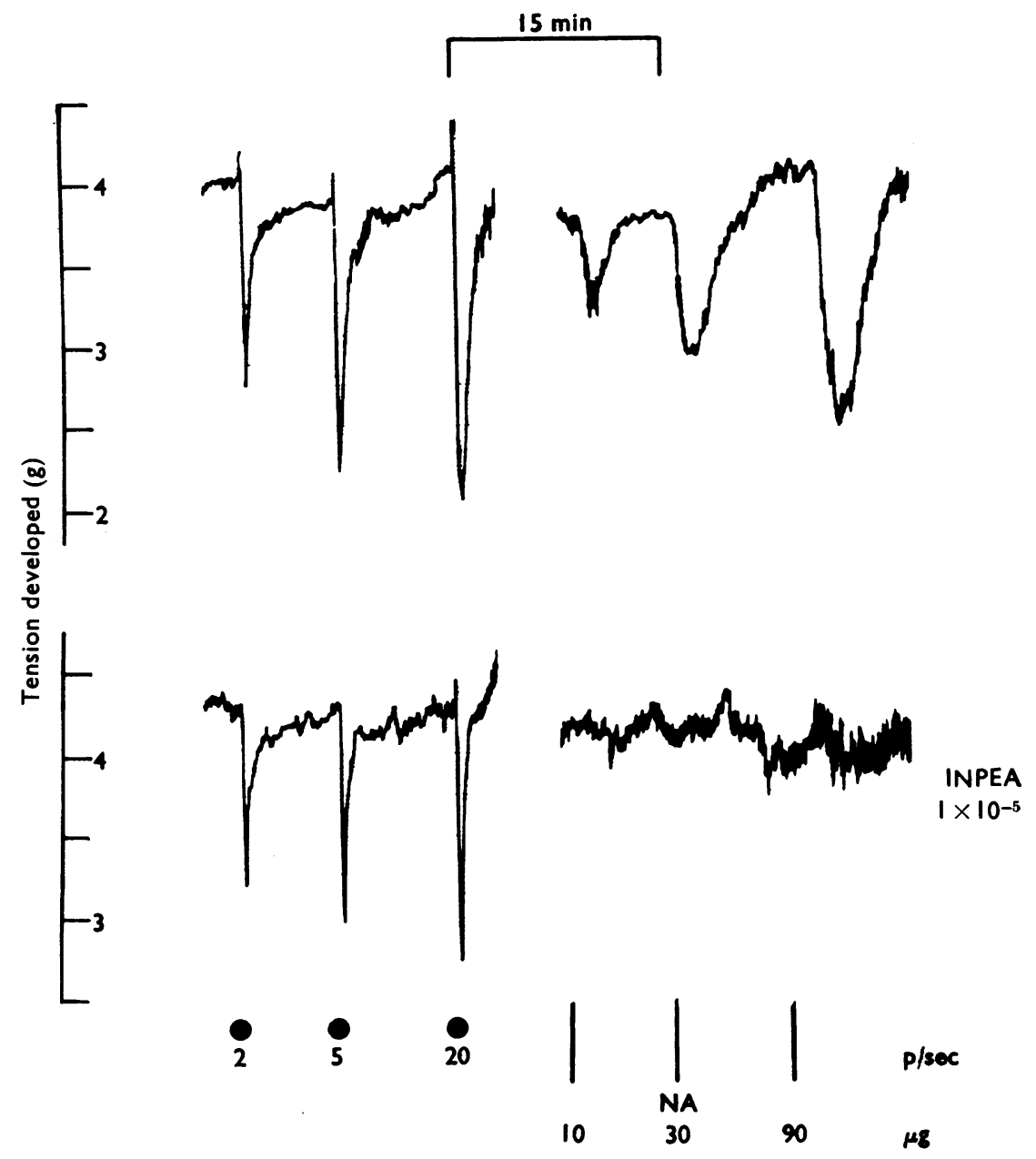

Fig. 13. Effect of INPEA on relaxations to electrical stimulation $(2,5,20 \mathrm{p} / \mathrm{sec}$ at dots) and to noradrenaline (NA ; 10, 30 and $90 \mu \mathrm{g})$ obtained in the presence of phentolamine $\left(5 \times 10^{-6} \mathrm{~g} / \mathrm{ml}\right.$.). Upper panel, before, and lower panel, $20 \mathrm{~min}$ after INPEA $\left(1 \times 10^{-5} \mathrm{~g} / \mathrm{ml}\right.$.), NA was completely blocked while relaxations to stimulation were only partially reduced in depth and duration. 
$10^{-5} \mathrm{~g} / \mathrm{ml}$.) both propranolol and pronethalol exhibited local anaesthetic activity, as shown by the selective reduction of contractions induced by electrical excitation, without reduction of those induced by noradrenaline. INPEA, a $\beta$-receptor blocking agent which has little or no local anaesthetic action (Somani \& Lunn, 1965) in concentrations of $10^{-5} \mathrm{~g} / \mathrm{ml}$. (three experiments), did not reduce relaxations induced by low frequency stimulation, and only slightly reduced the after-relaxations following higher rates of stimulation.

Several preparations were treated with $\alpha$-receptor blocking agents (phentolamine, ergotamine or dibenzyline) in concentrations sufficient to abolish the contractor responses to noradrenaline, adrenaline and electrical excitation and to disclose the relaxations to these stimuli. The relaxations induced by adrenaline and noradrenaline were completely abolished by propranolol $\left(10^{-6} \mathrm{~g} / \mathrm{ml}\right.$.) or by INPEA $\left(10^{-5} \mathrm{~g} / \mathrm{ml}\right.$.), but the relaxation induced by electrical stimulation (10 experiments) was reduced by only $10-50 \%$ (Fig. 13). We conclude that part of the relaxation induced during electrical excitation is mediated by release of catecholamines and is a $\beta$-receptor effect. The relaxation which remains after both $\alpha$ - and $\beta$-receptor block is discussed more fully in the next 'section.

The relaxation resistant to adrenergic neurone and receptor block. This relaxation was non-adrenergic in nature, since it could be obtained by electrical stimulation of preparations (a) from rabbits pretreated with reserpine, (b) in which adrenergic neurone block had been induced by bretylium or bethanidine and (c) in which both $\alpha$ - and $\beta$ receptors for catecholamines had been blocked. It was also obtained by electrical excitation of preparations which were maximally contracted by the addition of noradrenaline or adrenaline to the bath.

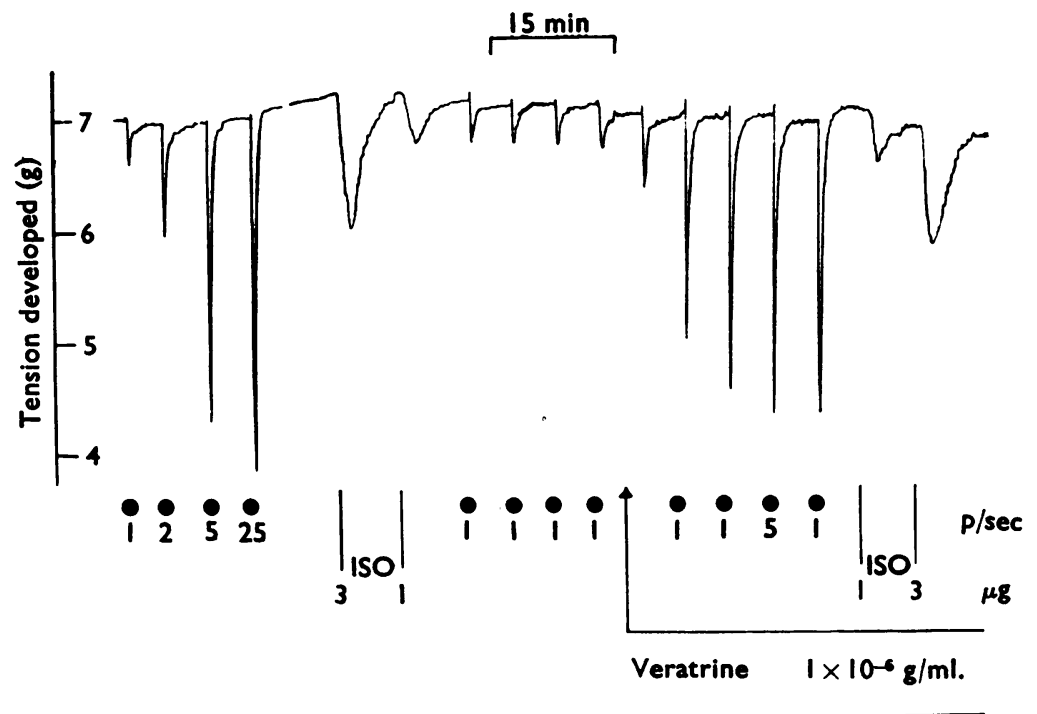

Bretylium $5 \times 10^{-6} \mathrm{~g} / \mathrm{ml}$.

Fig. 14. Potentiation by veratrine of the non-adrenergic relaxation. Responses to electrical stimulation $\left(1,2,5,25 \mathrm{p} / \mathrm{sec}\right.$ at dots) after adrenergic neurone block by bretylium $\left(5 \times 10^{-6} \mathrm{~g} / \mathrm{ml}\right.$.). Addition of veratrine $\left(1 \times 10^{-6} \mathrm{~g} / \mathrm{ml}\right.$. at $\left.\uparrow\right)$ induced a substantial increase in the response to stimulation at $1 \mathrm{p} / \mathrm{sec}$. There was no potentiation of the responses to isoprenaline (ISO 1 and $3 \mu \mathrm{g}$ ). Time scale $15 \mathrm{~min}$. 
The nature of the structures mediating the non-adrenergic relaxant response. The "chronaxie" of the response was between 0.1 and $0.5 \mathrm{msec}$ (six experiments). The relaxation was frequency dependent, increasing in size from $1 / \mathrm{sec}$ and becoming maximal at $20-30 / \mathrm{sec}$ (Fig. 14). Lignocaine or cocaine $\left(10^{-5} \mathrm{~g} / \mathrm{ml}\right.$.) reduced or abolished the relaxation, but at the same time the basal tone of the preparation was decreased. Veratrine $\left(5 \times 10^{-6} \mathrm{~g} / \mathrm{ml}\right.$.) increased the relaxation induced by stimulation at $1 / \mathrm{sec}$ to a size previously given by stimulation at $5 / \mathrm{sec}$ (Fig. 14). All of these results suggest that the non-adrenergic relaxation is induced by nerve stimulation. This conclusion was further substantiated by the effects of tetrodotoxin $\left(5 \times 10^{-7} \mathrm{~g} / \mathrm{ml}\right.$.), which abolished the relaxation during electrical excitation, whether this was in the presence of $\alpha$-receptor block only (four experiments) or in the presence of $\alpha$ - and $\beta$-receptor block (10 experiments ; Fig. 15). Of all antagonists tried, tetrodotoxin and local anaesthetics were the only ones which reduced the relaxation. Hyoscine, mepyramine and brom-lysergic acid diethylamide had no antagonistic effect, nor was the relaxation potentiated by anticholinesterase, or by low concentrations of cocaine.

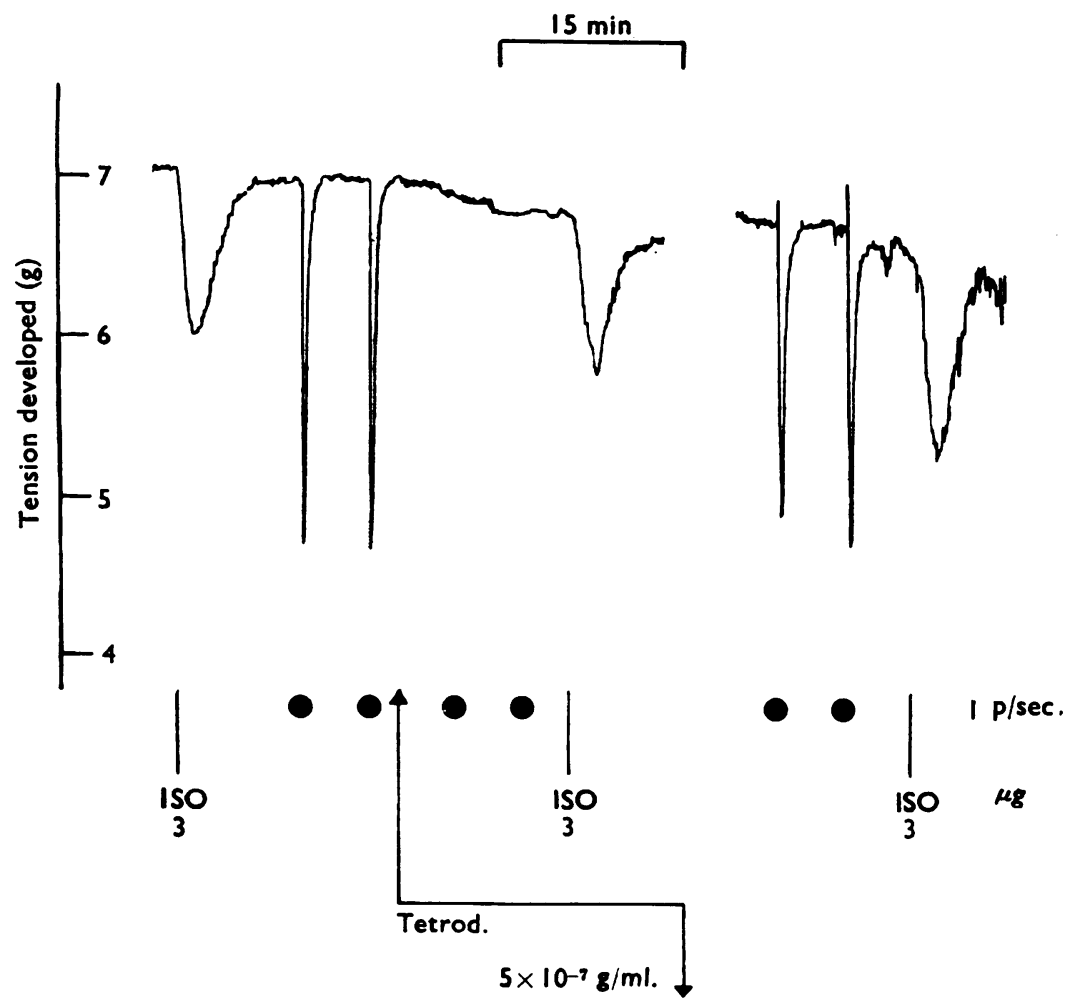

Fig. 15. Block by tetrodotoxin of the non-adrenergic quick relaxation. This tracing is a continuation of the experiment in Fig. 14 ; bretylium $\left(5 \times 10^{-6} \mathrm{~g} / \mathrm{ml}\right.$.), and veratrine $\left(1 \times 10^{-6} \mathrm{~g} / \mathrm{ml}\right.$.) were still present in the bath. Tetrodotoxin (Tetrod. $5 \times 10^{-7} \mathrm{~g} / \mathrm{ml}$. $\uparrow$ ) completely blocked the quick relaxation to stimulation ( $1 \mathrm{p} / \mathrm{sec}$ at dots); removing the tetrodotoxin from the bath $\downarrow$ restored the quick relaxation within $30 \mathrm{~min}$. Control relaxations to isoprenaline (ISO $3 \mu \mathrm{g}$ ) were unchanged. Time scale $15 \mathrm{~min}$. 


\section{DISCUSSION}

A number of nerve-smooth muscle preparations have been used in vitro to investigate autonomic nervous activity. Those with a separate excitable nerve trunk include the Finklemann preparation (Finklemann, 1930), the hypogastric nerve-vas deferens preparation (Huković, 1961), the nictitating membrane of the cat (Thompson, 1961), and the depressor nerve-aortic arch preparation of the rabbit (Bevan, 1962 ; Bevan \& Su, 1964). The principle of transmural stimulation (Paton, 1955) made it possible to stimulate intramural nerves obviating the need for a discrete nerve trunk. It has been applied to many intestinal preparations, but to very few vascular ones (Paterson, 1965; de la Lande \& Rand, 1965). The isolated portal vein preparation has a number of advantages as a model for the investigation of autonomic nerve function in smooth muscle; it is simple to prepare, robust, and gives reproducible responses to both electrical and chemical stimulation. Moreover, the interval between successive stimuli need not be greater than 6 min.

The portal vein also provides a useful model for studying the response of venous smooth muscle to nerve and drug stimulation. Unlike most arterial preparations, it is a spontaneously active tissue, and in this respect, it may well resemble the smaller blood vessels (Johansson \& Bohr, 1966). It also differs from arterial preparations in its sensitivity to drugs ; for instance histamine, 5-hydroxytryptamine, bradykinin and angiotensin all have relatively feeble effects when compared to the catecholamines. This differing sensitivity may well be linked with the separate function of venous and arterial tissue.

All the results show that transmural stimulation of the isolated portal vein of the rabbit stimulates nerves, or structures that respond similarly to nerves. Histochemical studies employing the Falck fluorescence technique, described in detail by Dahlström \& Fuxe (1964), have demonstrated the presence of adrenergic nerves in this tissue (Reinert, personal communication). All of the experiments, both with contractor substances and with antagonists, show that the contraction produced by electrical stimulation is mediated by release of catecholamine, presumably from such adrenergic nerves. The relative potentiation by cocaine of the contractions induced by noradrenaline, adrenaline and electrical stimulation, suggests that the mediator is noradrenaline.

The contraction produced by nerve excitation declines rapidly when the stimulation is stopped, indicating rapid inactivation of the noradrenaline. Uptake of the transmitter into "storage sites" probably plays a role in this inactivation since the duration of the contraction is prolonged in the presence of cocaine. Contractions induced by 5-hydroxytryptamine and histamine are probably also direct effects on the smooth muscle in the vein; however, both of these drugs are weak and neither can produce a contraction as great as those produced by catecholamines.

The paradoxical effect of acetylcholine in causing a contraction of isolated arterial tissue instead of relaxation is well documented (Furchgott, 1955), and may be related to lack of tone in the isolated vessel. Recently, de la Lande \& Rand (1965) showed that a vasodilatation to acetylcholine appears in the isolated perfused central artery of the rabbit ear when the arterial "tone" is raised by sympathetic stimulation. In the portal vein, acetylcholine does not produce a dilatation when the tone of the vessel is similarly 
raised. Inhibitory responses to acetylcholine have been observed in a few preparations and both the relaxation and contraction are abolished by hyoscine, suggesting that acetylcholine acts directly on muscarinic receptors to produce both excitatory and inhibitory effects.

Oxytocin, vasopressin and the adenine nucleotides all relax the portal vein; since neither INPEA nor propranolol antagonize these responses, it is unlikely that they are mediated through an action on $\beta$-receptors for adrenaline.

After block of $\alpha$-receptors, adrenaline and noradrenaline are approximately equipotent in causing relaxations of the portal vein. This is surprising since it is generally accepted that in vascular smooth muscle adrenaline possesses much greater $\beta$-receptor activity than noradrenaline (Ahlquist, 1948). However, noradrenaline has been shown to dilate the vessels in the human forearm after $\alpha$-receptor block (Brick, Hutchinson \& Roddie, 1966), and is a more potent dilator of isolated coronary vessels than adrenaline (Zuberbuhler \& Bohr, 1965). There is increasing evidence that the smooth muscle of the vascular tree is not a pharmacologically homogeneous system and even different sections of aorta may vary in their reactions to drugs (Somlyo, Sandberg \& Somlyo, 1965). It may well be that the relative $\beta$-receptor activity of noradrenaline and adrenaline differs with the vascular bed studied.

There are three types of relaxation which can be distinguished in response to transmural stimulation. They are all abolished, or almost abolished by tetrodotoxin, strongly suggesting that these relaxations are due to excitation of nerves. Pharmacological analysis shows that part of the relaxation is due to stimulation of adrenergic nerves. Thus, all three types resist the actions of hexamethonium, hyoscine, mepyramine and brom-LSD, but the first type is abolished by $\alpha$-receptor blocking agents. This relaxation, which lasts for 9-15 min, is frequently seen after a contraction induced by high rates of stimulation. In some preparations, a pure relaxation during low frequency stimulation was also recorded, but an increase in frequency induced a contraction, followed by the usual relaxation. It is interesting, however, that a pure relaxation could never be induced by noradrenaline.

After block of $\alpha$-receptors, a second type of relaxation is observed. It is seen at all frequencies, begins during stimulation and lasts $4-6 \mathrm{~min}$. It is partially reduced by block of $\beta$-receptors, suggesting that only part of this relaxation is adrenergic. This is confirmed by other experiments in which the adrenergic nerves or their effects are completely blocked but some relaxation still remains. Thus there is a third component of the relaxation which occurs after both $\alpha$ - and $\beta$-receptor block, in preparations from animals pretreated with reserpine, in preparations maximally contracted with noradrenaline, and after block of adrenergic neurones. Under these conditions, it is seen at all frequencies of stimulation, it begins during stimulation and it lasts for 1.5-3 min after a $10 \mathrm{sec}$ period of stimulation. It is maintained, however, if stimulation is continued.

Zimmerman (1966) has reported that sympathetic stimulation of the lumbar chain after bretylium caused a vasodilatation in the dog's paw; he suggests that there are histaminergic and cholinergic components to this response. Beck (1965) has also suggested that histamine is a mediator of active reflex dilatation in the dog, and that this histaminergic response is transmitted over the sympathetic system. The non-adrenergic relaxation to stimulation which we have observed is unlikely to be mediated by histamine, 
5-HT, or acetylcholine since specific antagonists of these substances do not reduce it. The transient nature of the non-adrenergic relaxation indicates an efficient inactivation mechanism, but at present we have no means of potentiating or antagonizing the response at the receptor level. Minute amounts of ATP have been shown to be released from nerves on depolarization (Abood, Koketsu \& Miyamoto, 1962), and it has also been implicated in the vasodilatation produced by antidromic stimulation in the rabbit ear (Holton, 1959). Release of ATP or a related nucleotide might account for the nonadrenergic relaxation. Reports of a similar non-adrenergic inhibitory response in isolated intestinal muscle are becoming more numerous (Paton \& Vane, 1963 ; Bucknell, 1965 ; Burnstock et al., 1966 ; Campbell, 1966). Burnstock and his co-workers suggest that the taenia caecum of the guinea-pig has intrinsic inhibitory nerves which function through the release of an unidentified transmitter. It has been suggested (Beck, DuCharme, Gebber, Levin \& Pollard, 1966) that there is a separate inhibitory system present in sympathetic nerves which can influence catecholamine release. If this is true, then the non-adrenergic relaxation may represent effects of such an inhibitory transmitter, which can only be detected when all adrenergic effects have been abolished. However, it is also possible that there are non-adrenergic nerves which have a function in controlling venous tone quite different from that of adrenergic nervous system.

\section{SUMMARY}

1. Isometric responses of an isolated preparation of the rabbit portal vein to electrical stimulation and to drugs have been studied.

2. The vein contracted strongly in response to adrenaline and noradrenaline but was relatively insensitive to histamine, acetylcholine, 5-hydroxytryptamine, angiotensin and bradykinin.

3. The vein relaxed in response to isoprenaline, vasopressin, oxytocin, the adenine nucleotides, and occasionally in response to acetylcholine.

4. Transmural electrical stimulation of the vein at frequencies between 1-50 pulses/ sec induced graded contractions which were abolished by $\alpha$-receptor blocking agents, adrenergic neurone blocking agents, pretreatment of the rabbit with reserpine, local anaesthetics and by tetrodotoxin. It was concluded that the contraction induced by electrical stimulation resulted from excitation of post-ganglionic sympathetic neurones.

5. A comparison of the relative potentiation by cocaine of the contractions induced by electrical stimulation, adrenaline and noradrenaline suggested that noradrenaline is the sympathetic transmitter mediating the effects of electrical stimulation.

6. Three types of inhibitory response to electrical stimulation were found; these were all abolished or considerably reduced by tetrodotoxin. Pharmacological analysis shows that some, but not all of the inhibitory effects were due to stimulation of adrenergic nerves leading to excitation of both $\alpha$ - and $\beta$-receptors.

7. Part of the relaxation was induced by excitation of non-adrenergic non-cholinergic nerve elements. The significance of this conclusion is discussed.

8. The advantages of this preparation for studying sympathetic nerve-smooth muscle mechanisms and as a model for studying venous smooth muscle activity are discussed. 
One of us (J. H.) would like to thank Professor J. G. Murray and Dr. M. J. Tsopogas for their encouragement, and the British Heart Foundation for a grant towards this work. We are grateful to Dr. J. W. Black for dL-INPEA, to I.C.I. for propranolol, and to Burroughs Wellcome for bretylium and bethanidine.

\section{REFERENCES}

Aвood, L. G., Koketsu, K. \& MiYamoto, S. (1962). Outflux of various phosphates during membrane depolarization of excitable tissues. Am. J. Physiol., 202, 469-474.

AHLquist, R. P. (1948). A study of adrenotropic receptors. Am. J. Physiol., 153, 586-600.

BECK, L. (1965). Histamine as the potential mediator of active reflex dilatation. Fedn Proc., 24, $1298-1310$.

Beck, L., DuCharme, D. W., Gebber, G. L., Levin, J. A. \& Pollard, A. A. (1966). Inhibition of adrenergic activity at a locus peripheral to the brain and spinal cord. Circulation Res., 18, supp. 1, 55-72.

BENTLEY, G. A. (1962). Studies on sympathetic mechanisms in isolated intestinal and vas deferens preparations. Br. J. Pharmac. Chemother., 19, 85-98.

BeVAN, J. A. (1962). Some characteristics of the isolated sympathetic nerve-pulmonary artery preparation of the rabbit. J. Pharmac. exp. Ther., 137, 213-218.

Bevan, J. A. \& Su, C. (1964). The sympathetic mechanism in the isolated pulmonary artery of the rabbit. Br. J. Pharmac. Chemother., 22, 176-182.

Birmingham, A. T. \& Wilson, A. B. (1965). An analysis of the blocking action of DMPP iodide on the inhibition of isolated small intestine produced by stimulation of the sympathetic nerves. $B r . J$. Pharmac. Chemother., 24, 375-386.

BOURA, A. L. A. \& GREEN, A. F. (1959). The actions of bretylium: adrenergic neurone blocking and other effects. Br. J. Pharmac. Chemother., 14, 536-548.

BRICK, I., HuTCHINSON, K. J. \& RodDIE, I. C..(1966). The vasodilator properties of noradrenaline. J. Physiol., 185, 42-43P.

BuCKNel, A. (1965). Effects of direct and indirect stimulation on isolated colon. J. Physiol., 177, $58-59 \mathrm{P}$.

Bülrring, E. \& Tomita, T. (1966). Evidence supporting the assumption that the " inhibitory potential" in the taenia coli of the guinea-pig is a post-synaptic potential due to nerve stimulation. J. Physiol., 185, 24-25P.

Burnstock, G., Campbell, G. \& RAND, M. J. (1966). The inhibitory innervation of the taenia of the guinè-pig caecum. J. Physiol., 182, 504-526.

CAmprell, G. (1966). The inhibitory nerve fibres on the vagal supply to the guinea-pig stomach. $J$. Physiol., 185, 600-612.

CASs, R. \& SPRIGGs, T. L. B. (1961). Tissue amine levels and sympathetic blockade after guanethidine and bretylium. Br. J. Pharmac. Chemother., 17, 442-450.

DAHLSTRÖM, A. \& FUXE, K. (1964). Evidence for the existence of monoamine-containing neurons in the central nervous system. I. Demonstration of monoamines in the cell bodies of brain stem neurons. Acta physiol. scand., 62, Suppl. No. 232.

DAY, M. D. (1962). Effect of sympathomimetic amines on the blocking action of guanethidine, bretylium and xylocholine. Br. J. Pharmac. Chemother., 18, 421-439.

DAY, M. D. \& RAND, M. J. (1963). Evidence for a competitive antagonism of guanethidine by dexamphetamine. Br. J. Pharmac. Chemother., 20, 17-28.

DAY, M. \& VANE, J. R. (1963). An analysis of the direct and indirect actions of drugs on the isolated guinea-pig ileum. Br. J. Pharmac. Chemother., 20, 150-170.

Finkleman, B. (1930). On the nature of inhibition in the intestine. J. Physiol., 70, 145-157.

Frankin, K. J. (1925). The circulation in the mesenteric vein of the sheep. J. Physiol., 59, 74-75P.

FurCHgotT, R. F. (1955). The pharmacology of vascular smooth muscle. Pharm. Rev., 7, 183-265.

Holton, P. (1959). The liberation of adenosine triphosphate on antidromic stimulation of sensory nerves. J. Physiol., 145, 494-504.

Huković, S. (1961). Responses of the isolated sympathetic nerve-ductus deferens preparation of the guinea-pig. Br. J. Pharmac. Chemother., 16, 188-194.

IVERSEN, L. L. (1965). The uptake of adrenaline by the rat isolated heart. Br. J. Pharmac. Chemother., 24, 387-394.

Johansson, B. \& BoHR, D. F. (1966). Rhythmic activity in smooth muscle from small subcutaneous arteries. Am. J. Physiol., 210, 801-806.

KIRPEKAR, S. M. \& FURCHGOTT, R. F. (1964). The sympathomimetic action of bretylium on isolated atria and aortic smooth muscle. J. Pharmac. exp. Ther., 143, 64-76.

De LA LANDE, I. S. \& RAND, M. J. (1965). A simple isolated nerve-blood vessel preparation. Aust. J. exp. Biol. med. Sci., 43, 639-656. 
Narahashi, T., Moore, J. W. \& ScotT, W. R. (1964). Tetrodotoxin blockage of sodium conductance increase in lobster giant axons. J. gen. Physiol., 47, 965-974.

PAterson, G. (1965). The response to transmural stimulation of isolated arterial strips and its modification by drugs. J. Pharm. Pharmac., 17, 341-349.

Paton, W. D. M. (1955). The response of the guinea-pig ileum to electrical stimulation by co-axial electrodes. J. Physiol., 127, 40-41P.

Paton, W. D. M. \& VANE, J. R. (1963). An analysis of the responses of the isolated stomach to electrical stimulation and to drugs. J. Physiol., 165, 10-46.

SOMANI, P. \& LUM, K. B. (1965). The antiarrhythmic actions of beta adrenergic blocking agents. $J$. Pharmac. exp. Ther., 147, 194-204.

Somlyo, A. V., SANDBerg, R. L. \& Somlyo, A. P. (1965). Pharmacologically heterogeneous smooth muscle cell distribution in blood vessels. J. Pharmac. exp. Ther., 149, 106-112.

SPIVACK, M. (1943). On presence or absence of nerves in umbilical blood vessels of man and guinea pig. Anatomy Res., 85, 85-109.

Surter, M. C. (1965). The pharmacology of isolated veins. Br. J. Pharmac. Chemother., 24, 742-751.

Thompson, J. W. (1961). The nerve supply to the nictitating membrane of the cat. J. Anatomy, 95, 371-385.

Wilson, A. B. (1962). An adrenergic neurone blocking action of dimethylphenylpiperazinium. J. Pharm . Pharmac., 14, 700.

ZnMmerman, B. G. (1966). Sympathetic vasodilation in the dog's paw. J. Pharmac. exp. Ther., 152, 81-87.

ZUBERBUHLER, R. C. \& BOHR, D. F. (1965). Responses of coronary smooth muscle to catecholamines Circulation Res., 16, 431-440. 